\title{
SOME HEALTH HAZARD METALS IN COMMERCIALLY IMPORTANT COASTAL MOLLUSCAN SPECIES IN BANGLADESH
}

Md. Shafiqul Islam, Md. Simul Bhuyan*, Md. Mostafa Monwar and Aysha Akhtar

$$
\text { Institute of Marine Sciences and Fisheries, University of Chittagong, }
$$
Chittagong 4331, Bangladesh

\begin{abstract}
The present study was conducted to measure the heavy metals $(\mathrm{Pb}, \mathrm{Cd}$, $\mathrm{Hg}$ ) concentrations in the muscles of four edible mollusk species (Perna viridis, Crassostrea crassostrea, Sepia officinalis and Loligo edulis) for two seasons. The heavy metal concentrations were analyzed by Atomic Absorption Spectrophotometer (AAS). The wet weight concentration of heavy metals varied for $\mathrm{Pb}: 0.03-0.05$ $1 \mathrm{mg} / \mathrm{kg}, \mathrm{Cd} 0.03-0.04 \mathrm{mg} / \mathrm{kg}$ and $\mathrm{Hg} 0.01-0.023 \mathrm{mg} / \mathrm{kg}$. The trend of metals in mollusk muscles were found $\mathrm{as} \mathrm{Pb}>\mathrm{Cd}>\mathrm{Hg}$. There was no significant variation of $\mathrm{Cd}$ and $\mathrm{Hg}$ concentrations in mollusk species that were analyzed, but $\mathrm{Pb}$ varied $(\mathrm{F}=$ 22.297; $\mathrm{p}=0.00$ ), in terms of both seasons and species. Principal Component Analysis and correlation matrix showed significant anthropogenic intrusions of $\mathrm{Pb}$, $\mathrm{Cd}$ and $\mathrm{Hg}$ in mollusks. There was significant positive correlation between $\mathrm{Cd}$ vs $\mathrm{Pb}$ (1.00) and $\mathrm{Hg}$ vs $\mathrm{Cd}(0.447)$ indicates their common origin especially from industries and municipal wastes. The determined concentrations of all metals in the present study were lower than the limits permitted by World Health Organization (WHO) and European Union (EU) guidelines.
\end{abstract}

Key words: Heavy metals, edible, mollusks

\section{INTRODUCTION}

Bivalves known as bioindicators of heavy metals pollution (Bryan et al. 1985, Goldberg et al. 1978, Burns and Smith 1981, Martin and Richardson 1991, Rainbow 1995, O’Connor 1996, 1998, Cantillo 1998, Lauenstein and Daskalakis 1998) in coastal areas because they tend to concentrate (Netpae and Phalaraksh 2009) trace metals. Long life span, high density and sessile (Otchere 2003, Rainbow 2007) nature make this creatures suitable for metal accumulation. These metals mainly originated from anthropogenic and natural sources (Gabr et et al. 2008, Yu et al. 2011, Muhammad et al. 2011, El Nemr et al. 2012, Salman 2012). Some heavy metals have adverse effects on aquatic organisms (Islam and Tanaka 2004, Yi et al. 2011) when accumulated at high concentrations ultimately causing human health risks when these organisms consumed (de Gieter and Baeyens 2005, Peter and Viraraghavan 2005). In comparison with other types of aquatic pollution, though the effects of heavy metal less visible, but the adverse effects on ecosystem and humans are intense and extensive due to their toxicity and their ability to accumulate in the biota

*Corresponding author: simulbhuyan@gmail.com

(c) 2016 Zoological Society of Bangladesh DOI: $10.3329 /$ bjz.v44i1.30182 
(Shanmugam et al. 2007, Edem et al. 2008). Though some metals are essential for human growth, development, achievement, and reproduction (Hogstrand and Haux 2001), but excessive amount can cause serious illness (Damek-Proprawa andSawicka-Kapustak 2003, Yi et al. 2011). Many researches carried out in the bioaccumulation of heavy metals in aquatic mollusks in different aquatic systems worldwide (Demina et al. 2009, Netpae and Phalaraksh 2009, Amisah et al. 2009, Shanmugam et al. 2007, Liu et al. 2007, Turkmen et al. 2005, Ohimain et al. 2008, Gaber et al. 2008, Salman 2006). Mollusks are very popular to coastal tribal people of Cox's Bazar but unfortunately very limited researches were done on heavy metal accumulation in mollusks in this area. This present research was conducted to determine the concentration of heavy metals and to assess the potential health risks at Cox's Bazar area.

\section{MATERIAL AND METHODS}

Mollusk samples were collected from two points (Moheskhali Channel and fish landing centre) of Cox's Bazar (Fig. 1).

A total of 4 mollusk species were collected for individual season and then identified (following Quddus and Shafi 1983, Quddus et al. 1988, Roy et al. 2007, Rahman et al. 2009). After collection the mollusks were placed immediately in poly-ethylene bags and then kept into isolated container of polystyrene icebox. Finally, the samples were transferred to the Bangladesh Council of Scientific and Industrial Research (BCSIR) in ice box (Irwandi and Farida 2009, Ismail and Saleh 2012) where the mollusks were first washed with deionized water then sealed in polyethylene bags and kept in a freezer at $-20^{\circ} \mathrm{C}$ till analysis (Elnabris et al. 2012).

The heavy metal contents were determined by AAS using standard analytical procedure. To avoid contamination, glasswares were properly cleaned in acid water and the reagents used were of analytical grade. Deionized water was used throughout the study. Reagents blank determinations were used to correct the background errors. The techniques for samples preparation, standard preparation, analysis for metal analyses have been briefly described below.

This procedure was also used for destruction of organic matter. Precaution was to be taken to avoid losses by volatilization of elements. At first samples were homogenized. Then the samples were weighed accurately a suitable quantity (10 to $20 \mathrm{~g}$ ) of the homogenized samples in a tared silica dish. After that the samples were dried at $100^{\circ} \mathrm{C}$ in a laboratory oven. These dishes were then placed in the muffle furnace at ambient temperature and slowly raised temperature to $450^{\circ} \mathrm{C}$ at a rate of no more than $50^{\circ} \mathrm{C} / \mathrm{h}$. The samples were ignited in a Muffle furnace at $450^{\circ} \mathrm{C}$ for at least $8 \mathrm{hrs}$. or overnight. After ashing was completed and cool, then the dishes were removed from furnace. Then the 
ashes were dissolved in diluted nitric acid (Afthan et al. 2000). The solutions were returned to a hot plate and continued heating, adding additional acid as necessary until digestion was completed. Then the samples were filtrated into a $100 \mathrm{ml}$ volumetric flask using Whatman No. 44 filter paper and washed the residue. Each sample solution was made up to the mark with distilled water.

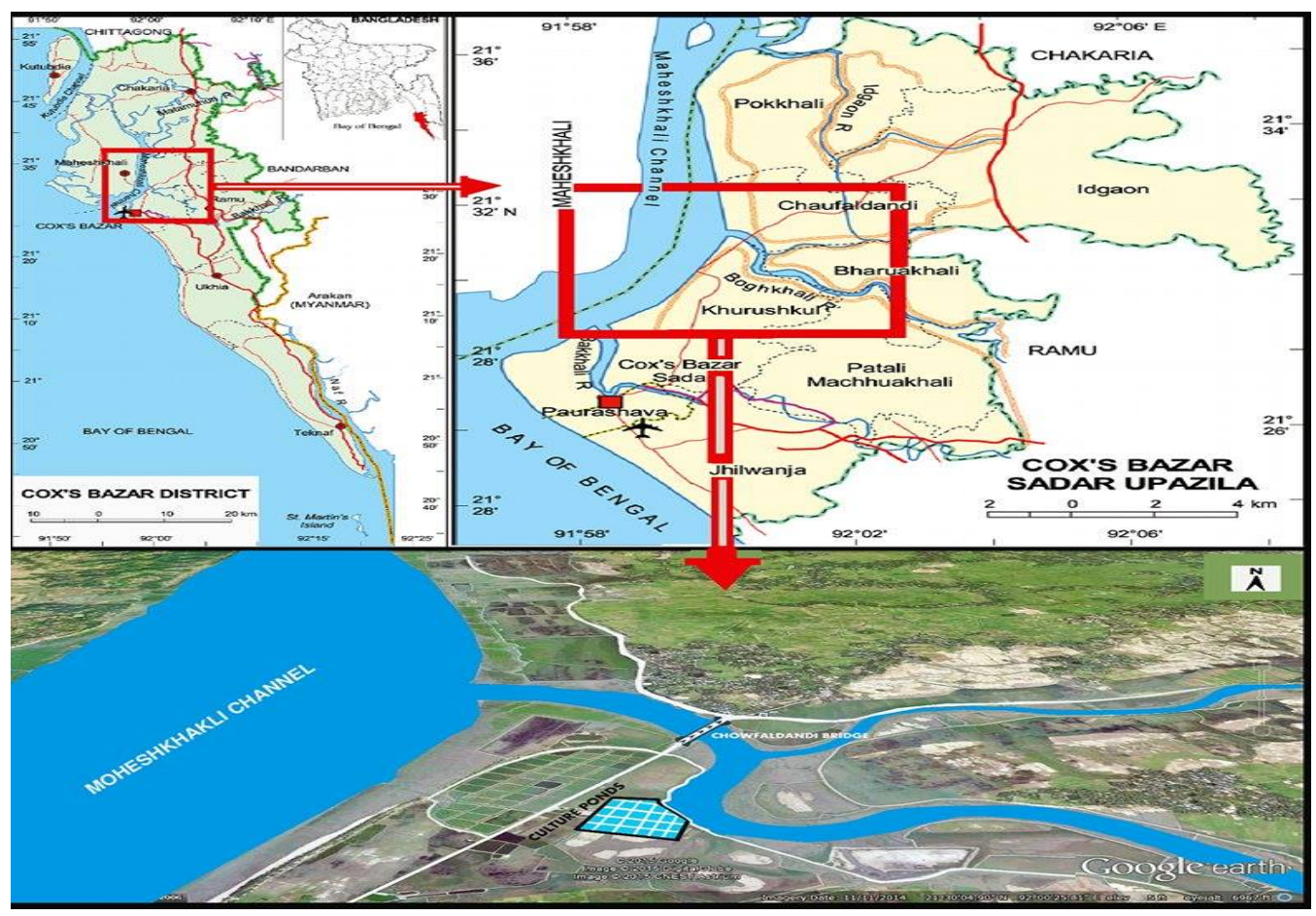

Fig. 1. Map showing sampling location.

Every metal standard solution was prepared for calibration the instrument for each element being determined on the same day as the analyses were performed due to possible deterioration of standard with time. All samples were prepared from chemicals of analytical grade with distilled water. $1 \mathrm{gm}$ of metal cadmium, copper, lead, nickel were dissolved in $\mathrm{HNO}_{3} ; 1 \mathrm{~g}$ of cobalt, iron, manganese, zinc, aluminum were dissolved in $\mathrm{HCl} ; 2.8289 \mathrm{~g} \mathrm{~K}_{2} \mathrm{Cr}_{2} \mathrm{O}_{7}$ (= one $\mathrm{g}$ chromium) was dissolved in water and made up to 1 liter in volumetric flask with distilled water, thus stock solution of $1000 \mathrm{mg} / 1$ of $\mathrm{Cd}, \mathrm{Cu}, \mathrm{Pb}, \mathrm{Ni}, \mathrm{Co}, \mathrm{Fe}$, $\mathrm{Mn}, \mathrm{Zn}, \mathrm{Al}$ and $\mathrm{Cr}$ were prepared (Cantle 1982). Then $100 \mathrm{ml}$ of 0.1, 0.25, 0.5, $0.75,1.0$ and $2.0 \mathrm{mg} / 1$ of working standards of each metal except iron were prepared from these stock using micropipettes in $5 \mathrm{ml}$ of $2 \mathrm{~N}$ nitric acid. One hundred $\mathrm{ml}$ of $2.0,2.5,5.0,10.0$ and $20.0 \mathrm{mg} / 1$ of working standards of iron metal were prepared from iron stock solution. Reagent blank was prepared in 
the same manners of sample preparation without sample to avoid reagents contamination.

Finally, the atomic absorption instrument was set up carefully. In the meantime, flame condition and absorbance were optimized for the analyte. Then blanks (deionized water), standards, sample blank and samples were aspirated into the flame in AAS (Model: iCE 3300, Thermo Scientific). The calibration curves were found for concentration vs. absorbance. Data were statistically analyzed using fitting of straight line by least square method. For more accuracy, a blank reading was also taken and necessary corrections were made during the calculation of various elements concentration.

One way analysis of variance (ANOVA) was done to show the variations in concentration of heavy metal in terms of seasons and mollusks. According to Dreher (2003), Principal Component Analysis (PCA) was performed on the original data set (without any weighting or standardization). Pearson's product moment correlation matrix was done to identify the relation among metals to make the result strong obtained from multivariate analysis.

\section{RESULTS AND DISCUSSION}

The specimens of four mollusk species (Perna viridis, Crassostrea crassostrea, Sepia officinalis and Loligo edulis) were analyzed for heavy metals ( $\mathrm{Pd}, \mathrm{Cd}$ and $\mathrm{Hg}$ ) determination. During winter season, the highest concentration of $\mathrm{Pb}$ was found in $\mathrm{S}$. officinalis $(0.051) \mathrm{mg} / \mathrm{kg}$. The lowest concentration was recorded in $P$. viridis $(0.03) \mathrm{mg} / \mathrm{kg}$ (Table 1 ). In case of $\mathrm{Cd}$, the maximum concentration documented in S. officinalis $(0.041) \mathrm{mg} / \mathrm{kg}$. Minimum amount was recorded in L. edulis $(0.03) \mathrm{mg} / \mathrm{kg}$. The highest value of $\mathrm{Hg}$ was recorded in $S$. officinalis $(0.023) \mathrm{mg} / \mathrm{kg}$ while lowest value was in C. crassostrea $(0.01)$ $\mathrm{mg} / \mathrm{kg}$. During rainy season, maximum amount of $\mathrm{Pb}$ was recorded in $S$. officinalis $(0.045) \mathrm{mg} / \mathrm{kg}$. Minimum concentration was measured in $P$. viridis (0.03) $\mathrm{mg} / \mathrm{kg}$ (Table 1 ). The highest value was recorded in L. edulis (0.045) $\mathrm{mg} / \mathrm{kg}$ and the lowest value recorded in $P$. viridis $(0.03) \mathrm{mg} / \mathrm{kg}$. The maximum concentration was found in C. crassostrea (0.02) $\mathrm{mg} / \mathrm{kg}$ while the minimum concentration was recorded in P. viridis (0.01), S. officinalis (0.01) and L. edulis (0.01) $\mathrm{mg} / \mathrm{kg}$ (Table 1).

In aquatic habitat, the relationship among metals in mollusks provide prevalent information about sources and pathways of variables. The result of correlations between heavy metals comply with the results found by PCA and CA that affirm some new associations between parameters. There was significant positive correlation between $\mathrm{Cd}$ vs $\mathrm{Pb}(1.00)$ and $\mathrm{Hg}$ vs $\mathrm{Cd}(0.447)$ that revealed their common origin especially from industries and municipal wastes (Table 2) 
Table 1. Heavy metal concentrations $(\mathrm{mg} / \mathrm{kg})$ in mollusks during Winter and Rainy season

\begin{tabular}{lccc}
\hline Name of species & Heavy metals & Winter season & Rainy season \\
\hline Perna viridis (L.) & $\mathrm{Pb}$ & 0.03 & 0.03 \\
& $\mathrm{Cd}$ & 0.04 & 0.03 \\
Cressostrea. crassostrea & $\mathrm{Hg}$ & 0.011 & 0.01 \\
& $\mathrm{~Pb}$ & 0.05 & 0.04 \\
& $\mathrm{Cd}$ & 0.04 & 0.04 \\
Sepia officinalis & $\mathrm{Hg}$ & 0.01 & 0.02 \\
& $\mathrm{~Pb}$ & 0.051 & 0.045 \\
& $\mathrm{Cd}$ & 0.041 & 0.04 \\
Loligo edulis & $\mathrm{Hg}$ & 0.023 & 0.01 \\
& $\mathrm{Ld}$ & 0.05 & 0.035 \\
& $\mathrm{Cd}$ & 0.03 & 0.045 \\
& $\mathrm{Hg}$ & 0.02 & 0.01 \\
\hline
\end{tabular}

Table 2. Correlation matrix of heavy metals in mollusks

\begin{tabular}{lllll}
\hline & & Lead & Cadmium & Mercury \\
\hline Correlation & Lead & 1.000 & & \\
& Cadmium & 1.000 & 1.000 & \\
& Mercury & 0.447 & 0.447 & 1.000 \\
\hline
\end{tabular}

Table 3. Component matrix of two factors model with strong to loadings in mollusks

\begin{tabular}{lcc}
\hline Parameters & \multicolumn{2}{c}{ Component } \\
\cline { 2 - 3 } & PC 1 & PC 2 \\
\hline Lead & 0.966 & -0.257 \\
Cadmium & 0.966 & -0.257 \\
Mercury & 0.662 & 0.750 \\
Eigen value & 2.306 & 0.694 \\
\% Total variance & 76.874 & 23.126 \\
Cumulative \% & 76.874 & 100.000 \\
\hline
\end{tabular}

Eigen values used as the extraction method to find out the principal components in PCA analysis. The components considered as principal components whose Eigen values was greater than 0.6 were taken into account. Two PCs were extracted by using correlation matrix which reflects the processes influencing the heavy metals composition having $100.0 \%$ of total sample variance (Table 3). The total variance of the PCs were 76.874 and $23.126 \%$ for PC 1 and PC 2, respectively. PC 1 is strongly correlated with $\mathrm{Pb}, \mathrm{Cd}, \mathrm{Hg}$ and PC 2 with $\mathrm{Hg}$. The source of PC 1 and PC 2 can be considered as mixed source from anthropogenic inputs particularly from industrial effluents and agricultural activities in the study area. 
The concentration of toxic metals $(\mathrm{Pb}, \mathrm{Cd}, \mathrm{Hg})$ in 4 mollusk species were found to be below the WHO permissible concentrations given for seafood (WHO $1972,1987)$. The concentration of $\mathrm{Pb}$ varied between $(0.03-0.051) \mathrm{mg} / \mathrm{kg} /$ wet wt. that far below the limit set by the EU is $0.3 \mathrm{mg} / \mathrm{kg} /$ wet wt. (EU 2006). More or less similar result was found by (Staniskiene et al. 2006, Copat et al. 2012). Lead is extensively responsible for the reduced cognitive development and intellectual performance in children and augmented blood pressure and cardio vascular disease in adults (Commission of the European Communities 2001). The amount of $\mathrm{Cd}(0.03-0.04) \mathrm{mg} / \mathrm{kg} /$ wet wt. recorded in all mollusk species (P. viridis, C. crassostrea, S. officinalis and L. edulis) exceeded the limit (0.02 $\mathrm{mg} / \mathrm{kg}$ ) set by the (EU 2006). Cadmium can amass in the human body that might causes prostate cancer and breast cancer (Saha and Zaman 2012), kidney dysfunction, skeletal damage and reproductive deficiencies in human (Commission of the European Communities 2001). In the present study, estimated $\mathrm{Hg}$ concentration ranged between $(0.01$ and 0.023$) \mathrm{mg} / \mathrm{kg} /$ wet wt that was far below the European dietary limit of $0.5 \mathrm{mg} \mathrm{Hg} / \mathrm{kg}$ (Commission of the European Communities 2001). Mercury has acute toxicity that mercury may prompt changes in the normal development of the brain of newborns and at higher levels may induce neurological alterations in grown ups (Commission of the European Communities 2001). Mercury toxicity can affect the kidney, the developing fetus and it is a potential human carcinogen (Occupational Safety and Health Administration 2004).

\section{LITERATURE CITED}

AFTHAN, G., CUMONT, G., DYPDAHL, H.P. GADD, K., HARVRE, G.N., JULSHAMN, K., KAVERUD, K., LIND, B., LOIMARANTA, J., MERSEBURG, M., OISSON, PIEPPONEN, S., SUNDSTROM, B., UPPSTAD, B.J., WAALER, T. and WINNERSTAM, L. 2000. Determination of Metals in Foods by Atomic Absorption Spectrometry after Dry Ashing: NMKL1 Collaborative Study. LARS JORHEM. National Food Administration, Chemistry Division 2, Box 622, S-751 26 Uppsala, Sweden. Collaborators: Journal of AOAC International 83(5): 1204-1211.

AMISAH, S., ADJEI-BOATENG, D., OBIRKORANG, K.A. and QUAGRAINIE, K.K. 2009. Effects of clam size on heavy metal accumulation in whole soft tissues of Galatea paradoxa (Born, 1778) from the Volta estuary. Ghana. Inter. J. Fish. Aquacul. 1: 14-21.

BRYAN, G.W., LANGSTON, W.J., HUMMERSTONE, L.G. and BURT, G.R. 1985. A Guide to the Assessment of Heavy-Metal Contamination in Estuaries Using Biological Indicators, in: Marine Biological Association of the United Kingdom, Occasional Publication. 4: 92.

BURNS, K.A. and SMITH, J.L. 1981. Biological monitoring of ambient water quality: the case for using bivalves as sentinel organisms for monitoring petroleum pollution in coastal waters. Estuari, Coast. and She. Sci. 13:433-443. doi:10.1016/S0302-3524(81)80039-4.

CANTILLO, A.Y. 1998. Comparison of results of mussel watch programs of the United States and France with worldwide Mussel Watch studies. Mari. Pollut. Bulle. 36: 712-717. doi: 10.1016/S0025-326X(98)00049-6. 
COPAT, C., BELlA, F., CASTAING, M., FALliCO, R., SCIACCA, S. and FERRANTE, M. 2012. Heavy metals concentrations in fish from sicily (Mediterranean Sea) and evaluation of possible health risks to consumers. Bull. Environ. Contam. Toxicol. 88: 78-83.

COMMISSION OF THE EUROPEAN COMMUNITIES, 2001. Commission Regulation (EC) No. 221/2002 of 6 February 2002 amending regulation (EC) No. 466/2002 setting maximum levels for certain contaminants in foodstuffs. Official Journal of the European Communities, Brussels, 6 February 2002.

DAMEK-PROPRAWA, M. and SAWICKA-KAPUSTAK, K. 2003. Damage to the liver; kidney and testis with reference to burden of heavy metals in yellow-necked mice from areas around steelworks and zinc smelters in Poland. Toxicol. 186: 1-10.

DEMINA, L.L. GALKIN, S.V. and SHUMILIN, E.N. 2009. Bioaccumulation of some trace elements in the biota of hydrothermal fields of the Guaymas Basin (Gulf of California). Boletin De LA Sociae. Geologi. Mexica. 61: 31-45.

DREHER, T. 2003. Evaluation of graphical and multivariate methods for classification of water chemistry data. Hydrogeo. Jour. 11: 605-606.

EDEM, C.A., AKPAN, B. and DOSUNMU, M.I. 2008. A comparative assessment of heavy metals and hydrocarbon accumulation in Sphyrenaafra, Orechromisniloticus and lops lacerta from Anantigha Beach market in Calabar-Nigeria. Afr. J. Environ. Pollut. \& Health. 6: 61-64.

EUROPEAN UNION, 2006. Setting maximum levels for certain contaminants in foodstuffs, Commission Regulation (EC) No 1881/2006; OJ L 364, 20.12.2006. p. 5.

GABR, H.R. and GAB-ALLA, A.A. 2008. Effect of transplantation on heavy metal concentrations in commercial clams of Lake Timsah, Suez Canal, Egypt. Oceanologia 50: 83-93.

GIETER, M. DE. and BAEYENS, W. 2005. Arsenic in Fish: Implications for Human Health. Reviews in Food and Nutrition Toxicity, Taylor \& Francis, CRC Press, Boca Raton. U.S.A. 4: 57-83.

GOLDBERG, E.D., BOWEN, V.T., FARRINGTON, J.W., HARVEY, G., MARTIN, J.H., PARKER, P.L., Riseborough, R.W., ROBERTSON, W., SCHEINDER, E., GAMBIE, E. 1978. The Mussel Watch. Environ. Conservation 5: 101-125.

HOGSTRAND, C. and HAUX, C. 2001. Binding and detoxification of heavy metals in lower vertebrates with reference to metallothionein. Comparat. Bioche. and Physiol. Part C: Comparat. Pharmaco. 100:137-214. doi:10.1016/0742-8413(91)90140-O.

IRWANDI, J. and FARIDA, O. 2009. Mineral and heavy metal contents of marine fin fish in Langkawi Island, Malaysia, Inter. Food Res. Jour. 16: 105-112.

ISMAIL, I. and SALEH, I.M. 2012. Analysis of heavy metals in water and fish (Tilapia sp.) samples from TasikMutlara, Puchong. The Malaysi. Jour. of Analyti. Sci. 16: 346- 352.

ISLAM, M.D. and TANAKA, M. 2004. Impacts of pollution on coastal and marine ecosystems including coastal and marine fisheries and approach for management: a review and synthesis. Marine Pollut. Bulletin. 48: 624-649. doi:10.1016/j.marpolbul.2003.12.004.

KAMAL, J., ELNABRIS, SHAREEF, K., MUZYED, NIZAM, M. and El-ASGAR. 2012. Heavy metal concentrations in some commercially important fishes and their contribution to heavy metals exposure in Palestinian people of Gaza Strip (Palestine), Jour. of the Asso. of Arab Universiti. for Basic and Appli. Sci. 13: 44-51. http://dx.doi.org/10.1016/j.jaubas.2012.06.0.

LAUENSTEIN, G.G. and DASKALAKIS, K.D. 1998. US long-term coastal contaminant temporal trends determined from mollusk monitoring programs, 1965-1993. Marine Pollut. Bulletin 37: 6-13. 
LIU, C.W., LIANG, C.P., LIN, K.H., JANG, C.S., WANG, S.W., HUANG, Y.K. and HSUEH, Y.M. 2007. Bioaccumulation of arsenic compounds in aquaculture clams (Meretrixlusoria) and assessment of potential carcinogenic risks to human health by ingestion. Chemos. 69: 128-134.

MARTIN, M. and RICHARDSON, B. 1991. Long term contaminant biomonitoring: views from Southern and Northern hemisphere perspectives. Marine Pollut. Bulletin. 22: 533-537. doi:10.1016/0025-326X(91)90891-U.

MUHAMMAD, S., SHAH M.T., KHAN, S. 2011. Health risk assessment of heavy metals and their source apportionment in drinking water of Kohistan region, northern Pakistan. Micro chemi. Jour. 98: 334-343.

NEMR, A.E., KHALED, A., MONEER, A.A. and SIKAILY, A.E. 2012. Risk probability due to heavy metals in bivalve from Egyptian Mediterranean coast. The Egyp. Jour. of Aqua. Res. 38: 67-75. doi:10.1016/j.ejar.2012.11.001.

NETPAE, T. and PHALARAKSH, C. 2009. Water quality and heavy metal monitoring in water, sediments, and tissues of Corbicula sp. From Bung Boraphet Reservoir, Thailand. Chiang Mai. J. Sci. 36: 395-402.

OCCPATIONAL SAFETY and HEALTH ADMINISTRATION, 2004. Toxic Metals, Occupational Safety and Health Administration. US Department of Labor, 200 Constitution Avenue, NW, Washington, DC, available at: http://www.osha.gov.

O'CONNOR, T.P. 1996. Trends in chemical concentration in mussels and oysters collected along the US coast from 1986 to 1993. Marine Environ. Res. 41: 183-200. doi:10.1016/01411136(95)00011-9.

O'CONNOR, T.P. 1998. Mussel Watch results from 1986 to 1996. Marine Pollut. Bulletin 37: 14-19. doi:10.1016/S0025-326X(98)00126-X.

OHIMAIN, E., JONATHAN, G. and ABAH, S.O. 2008. Variations in heavy metal concentrations following the dredging of an oil well access canal in the Niger Delta. Advan. Biol. Res. 2: 97-103.

PETER, J. and VIRARAGHAVAN, T. 2005. A review of public health and environmental concerns. Environ. International 31: 493-501.

QUDDUS, M.M.A., SARKER, M.N. and BANERJEE, A.K.1988. Studies of the Chondrichthyes Fauna (Sharks, Skates and Rays) of the Bay of Bengal. The Journal of NOAMI 5(1 \&2): 19-39.

QUDDUS, M.M.A. and SHAFI, M. 1983. Bangapasagarer Matsya Sampad (The Fisheries Resources of the Bay of Bengal). Kabir Publications, 38/3, Bangla Bazar, Dhaka, Bangladesh. 535 pp.

RAHMAN, A.K.A., KABIR, S.M.H., AHMAD, M., AHMED, A.T.A., AHMED, Z.U., BEGUM, Z.N.T., HASSAN, M. A. and KHONDKER, M. 2009. Encyclopedia of Flora and Fauna of Bangladesh, Marine Fishes. Asiatic Soc. Bangladesh. 24: 2-57.

RAINBOW, P.S. 1995. Biomonitoring of heavy metal availability in the marine environment. Marine Pollut. Bulletin. 31: 183-192. doi:10.1016/0025-326X(95)00116-5.

ROY, B.J., DEY, M.P., ALAM, M.F. and SINGHA, N.K.2007. Present Status of shark fishing in the marine water of Bangladesh. UNEP/CMS/MS/Inf/10.17p. http://www. cms.int/bodies/ meetings/regional/sharks/pdf_docs/Inf_10_Bangladesh_Presentation_on_Shark_Fishing.pdf: Accessed 15 March, 2009.

SAHA, N. and ZAMAN, M. R. 2012. Evaluation of possible health risks of heavy metals by consumption of foodstuffs available in the central market of Rajshahi City, Bangladesh. Environ. Monit. Assess. 185: 3867-3878.DOI: 10.1007/s10661-012-2835-2.

SALMAN, J.M. 2006. Environmental study of some possible pollutants in Euphrates River between Hindia dam and Kufa-Iraq. Ph.D. Thesis. College of Science/Babylon University, Iraq. 
SHANMUGAM, A., PALPANDI, C. and KESAVAN, K. 2007. Bioaccumulation of some trace metals (Mg, $\mathrm{Fe}, \mathrm{Zn}, \mathrm{Cu})$ from Bowl Cymbiummelo (Solander, 1786). (A marine Neogastropod). Res. J. Environ. Sci. 1: 191-195.

STANISKIENE, B., MATUSEVICIUS, P., BUDRECKIENE, R. and SKIBNIEWSKA, K.A. 2006. Distribution of Heavy Metals in Tissues of Freshwater Fish in Lithuania. Polish J. Environ. Stud. 15: $585-591$.

TURKMEN, A., TURKMEN, M. and TEPE, Y. 2005. Biomonitoring of heavy metals from Iskenderun Bay using two Bivalve species Chama pacifica Broderip, 1834 \& Ostreastentina Payraudeau, 1826. Turk. J. Fish. Aquat. Sci. 5: 107-111.

WHO (World Health Organisation), 1972. Evaluation of certain food additives and the contaminants mercury, lead, cadmium. 16th Report of the Joint FAO/WHO Expert Committee on FoodAdditives. Technical Report Series 505, Geneva.

WHO (World Health Organisation), 1987. Evaluation of certain food additives and contaminants. 33rd Report of the joint FAO/WHO Expert Committee on Food Additives. WHO Technical Report Series 776, Geneva. 80 pp.

YU, G.B., LIU, Y., YU, S., WU, S.C., LEUNG, A.O.W., LUO, X.S., XU, B. and LI, H.B. 2011. Heavy metals in urban surface sediments. Chemosp. 85: 1080-1087.

YI, Y., YANG, Z. and ZHANG, S. 2011. Ecological risk assessment of heavy metals in sediment and human health risk assessment of heavy metals in fishes in the middle and lower reaches of the Yangtze River basin. Environmental Pollut. 159: 2575-2585.

(Manuscript received on 30 April, 2016; revised on 30 June, 2016) 